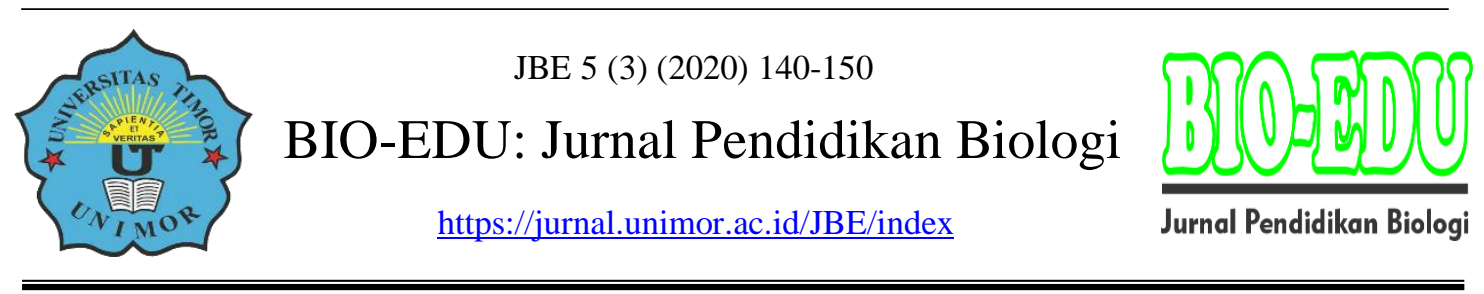

\title{
Diversity of Lichen in Mangrove Forest of Tomoli Village Parigi Moutong Regency
}

\section{Keanekaragaman Lichen di Hutan Mangrove Desa Tomoli Kabupaten Parigi Moutong}

\author{
Ari Pratama1, Manap Trianto ${ }^{2}$ \\ ${ }^{1}$ Program Studi Pendidikan Biologi, Fakultas Keguruan dan Ilmu Pendidikan, \\ Universitas Tadulako \\ ${ }^{2}$ Fakultas Biologi, Universitas Gadjah Mada \\ E-mail:aripratama590@gmail.com
}

DOI: https://DOI 10.32938/jbe. v5i3.730

\begin{abstract}
Abstrak
Lichen merupakan organisme hasil asosiasi simbiosis antara jamur dan alga dalam bentuk simbiosis mutualistik dan helotisme yang dapat membentuk kesatuan morfologi yang berbeda dengan spesies lain dari komponen penyusunnya. Penelitian ini bertujuan untuk menentukan tingkat keanekaragaman jenis lichen yang tumbuh pada hutan mangrove di Desa Tomoli Kabupaten Parigi Moutong. Penelitian ini dilaksanakan pada bulan Juli 2019. Metode yang digunakan dalam penelitian ini adalah metode survei teknik pengambilan sampel secara purposive sampling yaitu dengan menggunakan plot 10x10 $\mathrm{cm}$ pada pohon mangrove di setiap jalur pada lokasi penelitian. Berdasarkan hasil penelitian ditemukan 10 jenis lichen yang terdiri atas 6 genus, 5 famili, 7 ordo, dan 4 kelas yang terbagi atas dua kelompok yang berdasarkan tipe thallus yaitu lichen crustose dan foliose. Kelompok lichen crustose yaitu Aspicilia calcarea, Aspicilia sp., Pyrenula sp., Pyrenula dermatodes, Pyrenula santensis, Cryptothecia striata, Phaeographis sp., Graphis script, Verrucaria sp. Kelompok lichen foliose yaitu Flavoparmelia caperata. Nilai indeks keanekaragaman lichen yang didapatkan di hutan mangrove Desa Tomoli sebesar 2.225 yang menunjukkan bahwa tingat keanekaragaman sedang.
\end{abstract}

Kata Kunci: Desa Tomoli; Hutan Mangrove; Kabupaten Parigi Moutong; Keanekaragaman; Lichen

Abstract

Lichen is an organism resulting from a symbiotic association between fungi and algae in mutualistic symbiosis and eroticism, forming a morphological unity that is different from other species from its constituent components. This study aims to determine the level of lichen species diversity that grows in mangrove forests in Tomoli Village, Parigi Moutong Regency. This research was conducted in July 2019. The method used in this study was a survey method, the sampling technique was purposive sampling, namely by using a $10 \mathrm{~cm} \times 10 \mathrm{~cm}$ plot on the mangrove trees in each path at the research location. The research results found ten types of lichen consisting of six genera, five families, seven orders, and four classes divided into two groups based on the kind of thallus, namely lichen crustose and foliose. The crustose lichen group is Aspicilia calcarea, Aspicilia sp., Pyrenula sp., Pyrenula dermatodes, Pyrenula santensis, Cryptothecia striata, Phaeographis sp., Graphis script, Verrucaria sp. The foliose lichen group 
is Flavoparmelia caperata. The lichen diversity index value obtained in the mangrove forest in Tomoli Village was 2.225, indicating that the level of diversity is moderate.

Keywords: Tomoli Village; Mangrove Forest; Parigi Moutong Regency; Diversity; Lichen

\section{PENDAHULUAN}

Di alam populasi lichen tersebar luas hampir diseluruh jenis habitat. Dari 1000 jenis lichen yang ada didunia, 2500 jenis diketahui berada di Indonesia. Lichen merupakan tumbuhan perintis yang terdapat pada daerah yang keras dan kering sehingga pada akhirnya dapat mendukung pertumbuhan organisme lainnya (Haeryn, 2012: 25; Trianto et al., 2020: 21-29; Trianto et al., 2020: 199-209). Selanjutnya, Tjitrosoepomo (2009: 13-14) menambahkan bahwa lichen yang lazim dikenal dengan nama lumut kerak ini, keberadaannya masih belum banyak diketahui oleh orang, dan sesungguhnya berbeda dari lumut yang biasa dilihat. Lichen adalah tumbuhan epifit yang hidup pada beberapa jenis pepohonan. Lichen merupakan organisme yang bermanfaat sebagai penyerap zat kimia hasil air hujan dan polusi udara, serta sensitif terhadap racun sehingga berguna sebagai bioindikator peringatan dini untuk memantau kesehatan lingkungan (Yurnaliza, 2002: 28-49).

Bioindikator merupakan proses respon suatu mahluk hidup terhadap pengaruh yang timbul pada suatu lingkungan (Mahawati, 2011: 130-137; Trianto dan Marisa, 2020: 29-33). Secara umum, defenisi dari indikator biologis adalah organisme yang merespon berbagai faktor biotik dan abiotik disuatu lingkungan, sebagai bentuk dari dampak perubahan habitat atau lingkungan akibat zat kimia, maupun mengindikasikan sebagai perubahan suatu ekosistem atau komunitas secara keseluruhan dalam suatu area (Savic, 1998: 71-88; Mafaza et al., 2019: 10-16; Trianto dan Purwanto, 2020: 26192628; Trianto dan Purwanto, 2020: 186-193).

Lichen selain dapat mempengaruhi komponen ekosistem lainnya juga keberadaannya sangat dipengaruhi oleh keadaan lingkungan, misalnya tingkat pencemaran udara pada suatu wilayah. Oleh karena itu, lichen dapat dijadikan sebagai bioindikator pencemaran udara pada suatu lingkungan. Semakin jauh dari sumber polusi, keragaman lichen semakin bertambah dan spesies-spesies yang ditemukan akan berubah (Misra, 1978: 66-72; Mahawati, 2011: 130-137). Dalam hidupnya, lichen merupakan organisme yang terbentuk dari hasil asosiasi simbiosis antara jamur dan alga atau disebut sebagai simbiosis mutualistik dan helotisme yang dapat membentuk kesatuan morfologi yang berbeda dengan spesies lain dari komponen penyusunnya. Alga memiliki karakteristik berupa klorofil yang berfungsi dalam proses fotosintesis sedangkan fungi akan mengambil air dan mineral lainnya dari suatu lingkungan. Sedangkan helotisme maksudnya sifat parasit fungi terhadap alga dikarenakan hanya fungi yang mempunyai alat perkembangbiakan berupa badan buah atau thallus (Muzayyinah, 2005: 34-39; Murningsih \& Mafaza, 2019: 20-29).

Lichen hidup pada tempat yang bermacam-macam mulai dari substrat yang hidup sampai substrat yang mati. Sifat lichen yang bukan parasit menyebabkan organisme tersebut dapat hidup dimanapun dalam kondisi fisik yang bervariasi. Lichen sangat toleran pada suhu yang sangat dingin, tetapi sensitif terhadap suhu yang tinggi. Hal ini dikarenakan bentuk morfologinya yang sangat halus. Berdasarkan ketinggian, lichen hidup pada semua jenjang ketinggian mulai dari pantai, yaitu seperti pada 
kawasan hutan mangove sampai pegunungan yang tinggi (Khaerulmaddy, 2010: 10-17; Suprianto et al., 2020: 30-39; Trianto et al., 2020: 154-162).

Ekosistem mangrove merupakan kawasan tropika yang terdiri atas berbagai sumber daya alam didalamnya, baik yang bermanfaat pada aspek ekologi maupun sosial ekonomi. Di alam kawasan ini memegang peranan yang besar bagi kehidupan suatu organisme, dapat diketahui dari banyaknya jenis hewan, baik yang hidup di perairan, di atas lahan maupun di tajuk-tajuk pohon mangrove serta ketergantungan manusia terhadap ekosistem tersebut. Mangrove adalah salah satu jenis tumbuhan yang tahan atau toleransi terhadap salinitas laut terbuka. Mangrove merupakan komunitas vegetasi pantai baik tropis maupun subtropis yang didominasi oleh beberapa jenis pohon seperti Avicennia, Soneratia, Rhizophora, Bruguiera, Ceriops, Lumnitzera, Exoecarea, Xylocarpus, Scyphyphora, Aegiceras, dan Nypa yang mampu tumbuh dan berkembang pada daerah dengan karakteristik pasang surut pantai berlumpur (Ibansi, 2011: 13-21).

Hutan mangrove umumnya terdapat diseluruh pantai Indonesia dan dapat hidup serta tumbuh berkembang pada wilayah yang mempunyai hubungan pengaruh pasang air (pasang surut) yang merembes pada aliran sungai yang terdapat di sepanjang pesisir pantai. Keberadaan hutan mangrove mempunyai banyak peranan dalam suatu ekosistem, misalnya berfungsi sebagai tempat pelindung terhadap hempasan gelombang dan arus, sebagai tempat asuhan, sebagai tempat mencari makan, berkembang biak berbagai jenis biota laut, juga pohon mangrove sebagai tempat burung bersarang, tempat anggrek, pakis, benalu dan berbagai kehidupan lainnya temasuk lichen (Tarigan, 2008: 108-112). Salah satu hutan mangrove sebagai habitat lichen yang dapat dijadikan tempat penelitian yaitu hutan mangrove yang berada di Desa Tomoli, Kabupaten Parigi Moutong.

Selama ini, keanekaragaman jenis lichen pada hutan mangrove di Desa Tomoli belum diketahui secara maksimal sehingga perlu dilakukan penelitian di lingkungan tersebut. Berdasarkan hasil observasi yang telah dilakukan pada hutan mangrove Desa Tomoli. Salah satu jenis lichen yang ditemukan adalah Phaeographis sp. Hal ini mendorong untuk dilakukannya penelitian tentang keanekaragaman lichen di hutan mangrove Desa Tomoli.

\section{METODE}

\section{Waktu dan Tempat Penelitian}

Penelitian ini telah dilaksanakan pada bulan Juli 2019 di Hutan Mangrove, Desa Tomoli, Kabupaten Parigi Moutong, Provinsi Sulawesi Tengah. Kemudian dilanjutkan di Laboratorium Biologi, Fakultas Keguruan dan Ilmu Pendidikan (FKIP), Universitas Tadulako (UNTAD) untuk mengidentifikasi sampel dari lichen yang tercuplik. Penelitian yang dilaksanakan merupakan jenis penelitian deskriptif kuantitatif. Metode penelitian yang digunakan adalah metode survey dan teknik pengambilan sampel menggunakan metode plot dengan cara purposive sampling. Metode survey merupakan model penelitian dengan mengunjungi langsung lokasi penelitian, sedangkan purposive sampling adalah cara untuk menentukan lokasi penelitian dengan beberapa pertimbangan tertentu yang bertujuan agar data yang diperoleh nantinya bisa lebih representatif (Sugiyono, 2010: 87).

\section{Alat dan Bahan}

Alat dan bahan yang digunakan dalam penelitian yaitu meteran, thermometer, hygrometer, lux meter, pisau, kamera, buku identifikasi, alat tulis, kaca pembesar, 142 I Pratama \& Trianto/JBE 5 (3) (2020) 140-150 
kawat, alkohol, kawat, kertas label, plastik sampel, dan sampel lichen.

\section{Pelaksanaan Penelitian}

\section{Penentuan stasiun}

Penentuan lokasi penelitian berdasarkan kondisi hutan atau vegetasi yang ada di Desa Tomoli. Berdasarkan hal tersebut maka ditetapkan 2 stasiun pada area/lokasi penelitian yaitu Stasiun 1 ( 3 jalur) yang terletak pada bagian utara dan stasiun 2 (1 jalur) yang terletak pada bagian selatan Desa Tomoli.

Penentuan jalur transek

Penentuan jalur transek secara purposive sampling yaitu horizontal sejajar dengan garis pantai pada masing-masing stasiun. Panjang jalur transek yaitu $100 \mathrm{~m}$ dengan lebar $2.5 \mathrm{~m}$ ke arah kiri dan kanan dari garis transek, pada jalur transek dibuat 4 buah plot pada setiap pohon, yang diberi tanda A1 (bagian bawah pohon sebelah timur), A2 (bagian atas pohon sebelah timur), B1 (bagian bawah pohon sebelah barat) dan B2 (bagian atas pohon sebelah barat). Setiap plot berukuran 10x10 cm. Hal ini dilakukan mengingat ukuran lichen yang kecil. Selanjutnya, pohon yang dipilih harus ada jaraknya $\pm 10 \mathrm{~m}$, hal tersebut dilakukan agar data yang didapatkan tidak terulang antara pohon yang satu dengan yang lainnya.

\section{Pengambilan sampel}

Pengambilan sampel dilakukan dengan tahapan yaitu melakukan pengamatan lichen pada permukaan kulit pohon, pengamatan dimulai dari dasar hingga percabangan pertama pohon. Pada pohon-pohon yang tidak memiliki percabangan, pengambilan sampel dilakukan sampai ketinggian $\pm 2 \mathrm{~m}$ (Sudrajat, 2013: 75-79). Selanjutnya memotret menggunakan kamera dari setiap jenis lichen yang ditemukan, semua jenis lichen yang teridentifikasi ataupun yang belum diketahui jenisnya akan diambil menggunakan pisau dengan cara dikeruk kemudian diawetkan menggunakan alkohol dan dimasukkan dalam plastik sampel, pada tahap selanjutnya dilakukan identifikasi di laboratorium.

Pengukuran kondisi fisik kimia lingkungan

Pengukuran kondisi fisik-kimia lingkungan ekosistem mangrove Desa Tomoli Kabupaten Parigi Moutong adalah suhu dengan menggunakan thermometer, kelembaban dengan menggunakan hygrometer, dan intensitas cahaya dengan menggunakan lux meter.

\section{Pengidentifikasian sampel}

Identifikasi sampel lichen dilakukan di Laboratorium Biologi FKIP UNTAD. Hal yang dilakukan yaitu berupa pengidentifikasian dari jenis-jenis Lichen yang didapat dengan merujuk pada sumber referensi seperti buku How to know the lichens.

\section{Analisis Data}

Data keanekaragaman jenis-jenis lichen dihitung berdasarkan rumus keanekaragaman jenis dari Shannon-Wiener (Magurran, 2004: 155).

Keterangan :

$$
\mathrm{H}^{\prime}=-\sum \mathrm{Pi} \text { In } \mathrm{Pi} \quad \mathrm{Pi}=\text { ni } / \mathrm{N}
$$

H' = Indeks Keanekaragaman Shannon-Wienner

ni = Jumlah individu satu jenis

$\mathrm{N} \quad=$ Jumlah total individu semua jenis

$\mathrm{Pi} \quad=n \mathrm{i} / \mathrm{N}$ 
Berdasarkan indeks keanekaragaman jenis menurut Shannon-Wiener didefinisikan sebagai berikut:

Nilai H'> 3 menunjukkan bahwa keanekaragaman jenis adalah tinggi.

Nilai $H^{\prime} \leq H^{\prime} \leq 3$ menunjukkan bahwa keanekaragaman jenis adalah sedang.

Nilai H' $<1$ menunjukkan bahwa keanekaragaman jenis adalah sedikit atau rendah.

\section{HASIL DAN PEMBAHASAN}

Hasil

\section{Kondisi Fisik Kimia Lingkungan}

Kondisi fisik-kimia lingkungan merupakan faktor utama pertumbuhan setiap makhluk hidup dan salah satunya lichen. Berdasarkan hasil pengukuran kondisi fisikkimia lingkungan yang telah dilakukan meliputi suhu, kelembaban, dan intensitas cahaya diperoleh data kondisi fisik-kimia lingkungan yang disajikan dalam Tabel 1.

Tabel 1. Hasil pengukuran kondisi fisik kimia lingkungan

\begin{tabular}{llccc}
\hline \multirow{2}{*}{ No } & \multicolumn{1}{c}{ Parameter } & \multicolumn{2}{c}{ Stasiun } & \multirow{2}{*}{$\begin{array}{c}\text { Rata-rata Kondisi Fisik } \\
\text { Kimia Lingkungan }\end{array}$} \\
\cline { 3 - 4 } & & I & II & 32,60 \\
\hline 1 & Suhu $\left({ }^{\circ} \mathrm{C}\right)$ & 32,80 & 32,50 & 67,40 \\
2 & Kelembaban $(\%)$ & 67,70 & 67,20 & 1200 \\
3 & Intensitas cahaya $(\mathrm{Cd})$ & 1200 & 1200 & \\
\hline
\end{tabular}

\section{Jenis Lichen di Hutan Mangrove Desa Tomoli}

Berdasarkan hasil penelitian yang dilakukan mengenai keanekaragaman jenis lichen pada Hutan Mangrove di Desa Tomoli diperoleh 10 jenis lichen dari 5 famili. Data keanekaragaman lichen disajikan pada Tabel 2 dan Gambar 1.

Tabel 2. Jenis-jenis lichen yang ditemukan di Desa Tomoli

\begin{tabular}{clcc}
\hline No & \multicolumn{1}{c}{ Spesies } & Famili & Substrat \\
\hline 1. & Aspicilia calcarea (L.) Mudd & Megasporaceae & a, b, c \\
2. & Aspicilia sp. & Megasporaceae & a, b, c \\
3. & Pyrenula dermatodes (Borrer) Schaer & Pyrenulaceae & b, c \\
4. & Pyrenula santensis (Nyl) Mull. Arg & Pyrenulaceae & b, c \\
5. & Pyrenula sp. & Pyrenulaceae & $\mathrm{a}$ \\
6. & Flavoparmelia caperata (L.) Hale & Parmeliaceae & $\mathrm{b}, \mathrm{c}$ \\
7. & Cryptothecia striata (Ehrenb) G. & Arthoniaceae & $\mathrm{a}, \mathrm{c}$ \\
8. & Phaeographis sp. & Graphidacea & $\mathrm{a}, \mathrm{c}$ \\
9. & Graphis scripta (L.) Ach & Graphidaceae & $\mathrm{a}, \mathrm{b}$ \\
10. & Verrucaria sp. & Verrucariaceae & $\mathrm{b}$ \\
\hline
\end{tabular}

Keterangan substrat:

a : Avicennia marina (Forssk) Vierh.

$\mathrm{b}$ : Sonneratia alba J. Sm.

c : Rhizophora mucronata Lam. 


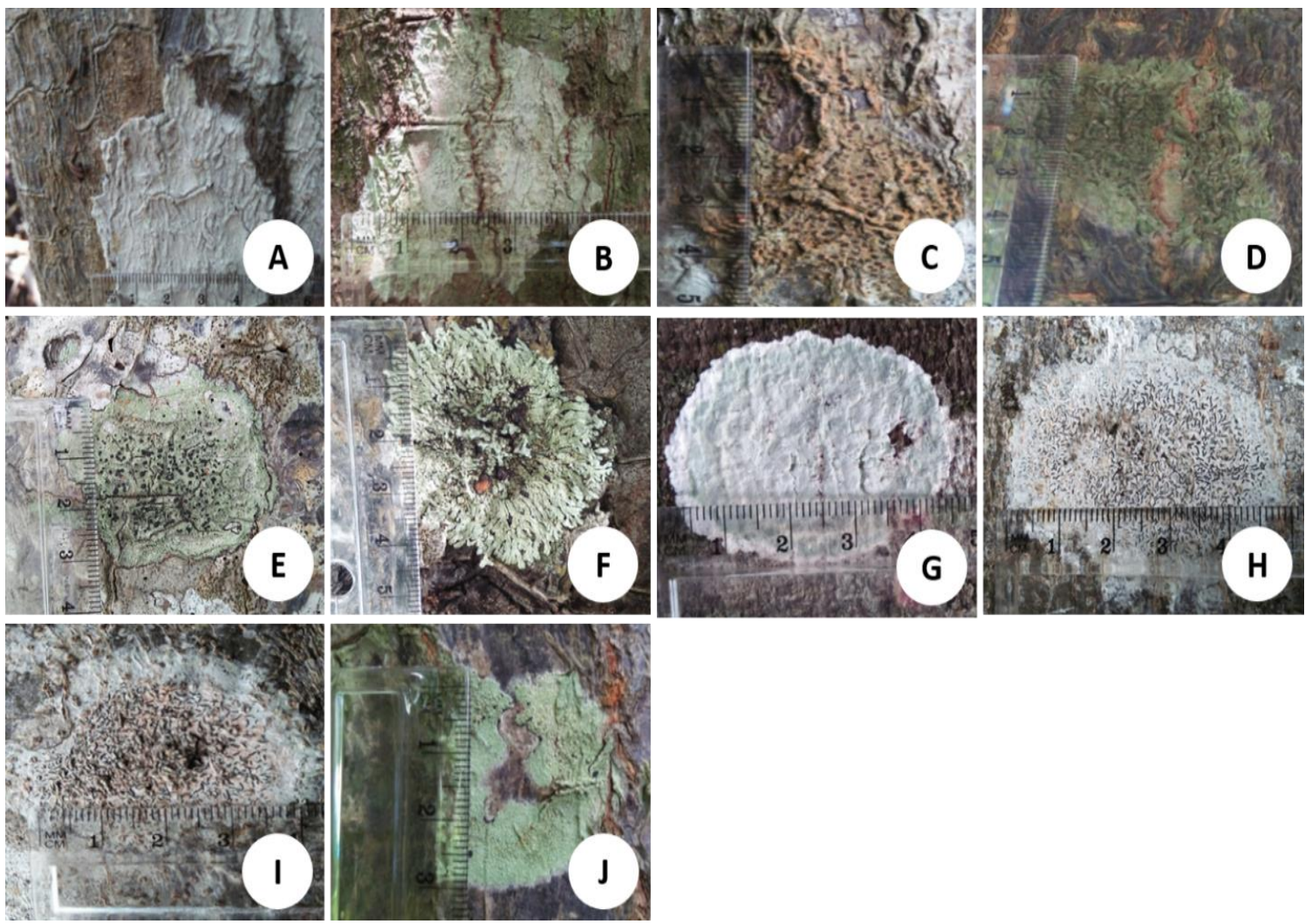

Gambar 1. Jenis-jenis lichen di Hutan Mangrove Desa Tomoli: A. Aspicilia calcarea (L.) Mudd, B. Aspicilia sp., C. Pyrenula dermatodes (Borrer) Schaer, D. Pyrenula santensis (Nyl) Mull. Arg, E. Pyrenula sp., F. Flavoparmelia caperata (L.) Hale, G. Cryptothecia striata (Ehrenb) G. Thor, H. Phaeographis sp., I. Graphis scripta (L.) Ach, dan J. Verrucaria sp.

Keanekaragaman Lichen di Hutan Mangrove Desa Tomoli

Berdasarkan hasil penelitian yang telah dilakukan, diperoleh jumlah individu setiap jenis bervariasi pada tiap-tiap stasiun. Variasi jumlah individu setiap jenis tersebut disajikan pada Tabel 3.

Tabel 3. Jumlah individu lichen yang didapatkan pada stasiun penelitian

\begin{tabular}{llccccc}
\hline & & \multicolumn{3}{c}{ Stasiun I } & Stasiun II & \\
\cline { 3 - 6 } No & \multirow{2}{*}{ Jenis Lichen } & & Jalur & Jalur & $\sum$ \\
\cline { 3 - 5 } & & I & II & III & I & \\
\hline 1 & Aspicilia calcarea & 23 & 27 & 22 & 25 & 97 \\
2 & Aspicilia sp. & 13 & 16 & 14 & 15 & 58 \\
3 & Pyrenula dermatodes & 12 & 9 & 11 & 15 & 47 \\
4 & Pyrenula santensis & 11 & 7 & 9 & 9 & 36 \\
5 & Pyrenula sp. & 9 & 8 & 7 & 11 & 35 \\
6 & Flavoparmelia caperata & 13 & 14 & 12 & 12 & 51 \\
7 & Cryptothecia striata & 9 & 9 & 10 & 9 & 37 \\
8 & Phaeographis sp. & 10 & 11 & 10 & 11 & 42 \\
9 & Graphis scripta & 11 & 10 & 9 & 9 & 39
\end{tabular}

145 IPratama \& Trianto/JBE 5 (3) (2020) 140-150 


\begin{tabular}{|c|c|c|c|c|c|}
\hline Verrucaria sp. & - & 5 & 6 & 10 & 21 \\
\hline Total & 111 & 116 & 110 & 126 & 463 \\
\hline
\end{tabular}

Selanjutnya, analisis mengenai tingkat keanekaragaman jenis lichen di Hutan Mangrove Desa Tomoli menggunakan indeks Shannon-Wienner. Dari hasil analisis, terlihat bahwa tingkat keanekaragaman lichen di Hutan Mangrove Desa Tomoli tergolong sedang (Tabel 4).

Tabel 4. Analisis keanekaragaman

\begin{tabular}{|c|c|c|c|c|c|c|}
\hline No. & Nama Jenis & $\sum$ & $\operatorname{Pi}(\mathrm{ni} / \mathrm{N})$ & $\ln (\mathrm{pi})$ & $\mathrm{Pi} \ln \mathrm{Pi}$ & $\mathrm{H}^{\prime}$ \\
\hline 1 & Aspicilia calcarea & 97 & 0.210 & -1.563 & -0.327 & 0.327 \\
\hline 2 & Aspicilia sp. & 58 & 0.125 & -2.077 & -0.260 & 0.260 \\
\hline 3 & Pyrenula dermatodes & 47 & 0.102 & -2.288 & -0.232 & 0.232 \\
\hline 4 & Pyrenula santensis & 36 & 0.078 & -2.554 & -0.199 & 0.199 \\
\hline 5 & Pyrenula sp. & 35 & 0.076 & -2.582 & -0.195 & 0.195 \\
\hline 6 & Flavoparmelia caperata & 51 & 0.110 & -2.206 & -0.243 & 0.243 \\
\hline 7 & Cryptothecia striata & 37 & 0.080 & -2.527 & -0.202 & 0.202 \\
\hline 8 & Phaeographis sp. & 42 & 0.091 & -2.400 & -0.218 & 0.218 \\
\hline 9 & Graphis scripta & 39 & 0.084 & -2.474 & -0.208 & 0.208 \\
\hline \multirow[t]{2}{*}{10} & Verrucaria sp. & 21 & 0.045 & -3.093 & -0.140 & 0.140 \\
\hline & Total & 463 & & & -2.225 & 2.225 \\
\hline
\end{tabular}

Keterangan:

$\mathrm{H}^{\prime}=-\sum(\mathrm{Pi} \ln \mathrm{Pi})$

$=-(-2.225)$

$=2.225$ (Tingkat keanekaragaman sedang)

Berdasarkan dari data di atas, menunjukkan bahwa indeks keanekaragaman lichen termasuk dalam kategori sedang karena terdapat pada kategori $1 \leq H^{\prime} \geq 3$.

\section{Pembahasan}

Berdasarkan hasil penelitian yang dilakukan di Hutan Mangrove Desa Tomoli Kabupaten Parigi Moutong ditemukan 10 jenis lichen yang terdiri atas 6 genus, 5 famili, 7 ordo, dan 4 kelas, yang terbagi atas dua kelompok berdasarkan tipe thallus yaitu lichen crustose dan foliose. Kelompok lichen crustose yaitu Aspicilia calcarea (L.) Mudd., Aspicilia sp., Pyrenula sp., Pyrenula dermatodes (Borrer) Schaer, Pyrenula santensis (Nyl) Mull. Arg, Cryptothecia striata (Ehrenb) G. Thor, Phaeographis sp., Graphis scripta (L.) Ach., Verrucaria sp. Sedangkan kelompok lichen foliose yaitu Flavoparmelia caperata (L.) Hale. Menurut Haeryn (2012: 31-43) dan Ruliansyah (2014: 66) bahwa lichen crustose memiliki thallus yang berukuran kecil, tipis, datar, dan selalu melekat ke permukaan batu, kulit pohon atau di tanah, jenis ini susah untuk dicabut tanpa merusak subtratnya. Lichen foliose memiliki struktur seperti daun yang tersusun oleh lobus-lobus. Lichen ini relatif lebih longgar melekat pada subtratnya. Thallusnya datar, lebar, banyak lekukan seperti daun yang mengkerut. Beberapa jenis lichen yang mampu hidup pada pohon Avicennia marina (Forssk) Vierh., Sonneratia alba J. Sm. dan Rhizophora mucronata Lam. dan ada pula yang tidak dapat hidup pada salah satu jenis pohon. Selanjutnya Melanstica (2016: 40-48) menjelaskan bahwa lichen dapat ditemukan di dalam ekosistem alami, misalnya kulit kayu pohon berbeda-beda 146 IPratama \& Trianto/JBE 5 (3) (2020) 140-150 
keasamannya, maka lichen yang berbeda toleransinya terdapat pada pohon-pohon yang berbeda.

Pada penelitian ini jenis lichen Aspicilia calcarea (L.) Mudd., Aspicilia sp., dan Flavoparmelia caperata (L.) Hale dapat ditemukan pada semua jenis pohon mangrove walaupun lingkungan ekosistem mangrove telah terpapar uap air garam, hal ini dikarenakan tingkat toleransi terhadap kondisi lingkungan berbeda dengan tingkat toleransi pada jenis lichen lainnya. Menurut Hadiyanti (2013: 12-17), bahwa ketahanan tumbuhan terhadap kadar garam secara fisiologi yaitu terakumulasinya beberapa senyawa yang dikenal dengan sebutan pelindung osmosis. Berdasarkan hasil penelitian pada kedua stasiun pengamatan ditemukan jenis yang sama pada tiap plot. Hal tersebut disebabkan oleh faktor fisik kimia lingkungan yang normal. Adapun hasil pengukuran kondisi fisik kimia lingkungan yaitu suhunya $32,60^{\circ} \mathrm{C}$, kelembaban $67,40 \%$ dan itensitas cahaya $1200(\mathrm{Cd})$.

Selain substrat, suhu juga merupakan salah satu faktor penting yang berpengaruh terhadap penyebaran lichen di alam. Hasil pengukuran suhu pada ekosistem mangrove di Desa Tomoli yaitu $32,60^{\circ} \mathrm{C}$. Menurut Istam (2007: 32), lichen dapat hidup baik pada suhu yang sangat rendah atau pada suhu yang sangat tinggi yang berkisar antara 18$30^{\circ} \mathrm{C}$. Hasil pengukuran kelembaban tempat ditemukannya lichen pada ekosistem mangrove yaitu 67,40\%, kelembaban sangat dipengaruhi oleh suhu udara. Menurut Istam (2007: 33), lichen dapat hidup baik pada kelembaban yang berkisar antara 40$89 \%$.

Lichen memiliki kisaran toleransi biologis yang cukup luas misalnya suhu. Lichen akan segera menyesuaikan diri bila keadaan lingkungannya kembali normal. Walaupun lichen tahan terhadap kekeringan dalam jangka waktu yang cukup panjang, namun lichen akan tumbuh secara optimal apabila lingkungan tersebut memiliki karakteristik yang lembab (Ronoprawiro, 1989: 71-77). Hasil pengukuran kondisi fisik tersebut merupakan kisaran toleransi bagi pertumbuhan dan perkembangan lichen. Artinya, lichen yang dapat tumbuh dan berkembang pada kondisi tersebut adalah lichen yang dapat beradaptasi dengan kondisi fisik demikian.

Roziaty (2016: 54-66) menyebutkan bahwa ada beberapa faktor yang dapat membantu proses penyebaran lichen disuatu lingkungan. Penyebaran secara vegetatif merupakan cara efisien yang dapat membantu penyebarannya, hal tersebut juga didukung oleh sifat lichen yang memiliki ketahanan terhadap suhu dan kelembaban yang ekstrim. Pertumbuhan lichen dipengaruhi oleh beberapa faktor lingkungan, antara lain suhu udara, kelembaban udara dan intensitas cahaya. Faktor lingkungan di atas menjelaskan jenis lichen yang didapatkan berbeda pada setiap lokasi penelitian.

Lichen yang ditemukan berasal dari substrat kulit pohon yang berbeda-beda, baik jenis pohon maupun tekstur kulit pohon. Tipe substrat sangat menentukan jenis lichen yang tumbuh, seperti halus kerasnya substrat, ketinggian, dan posisi substrat. Beberapa lichen mengekskresikan asam untuk memecahkan bebatuan, ada juga yang menggunakan organ seperti akar untuk menembus bebatuan atau permukaan batang pohon, sehingga lichen tersebut dapat tumbuh (Whitesel, 2006: 76-78; Murningsih \& Mafaza, 2019: 20-29). Artinya, lichen sangat tergantung dari kemampuan adaptasi mereka mencari tempat hidup atau substrat, agar lichen tersebut dapat bertahan hidup walaupun lingkungannya kurang sesuai. Faktor lain yang menentukan jenis dan kualitas pertumbuhan lichen yaitu kadar garam berupa uap air.

Lichen yang paling banyak ditemukan yaitu jenis Aspicilia calcarea dan yang paling sedikit adalah jenis Verrucaria sp. Hal ini terjadi karena adanya pebedaan 147 I Pratama \& Trianto/JBE 5 (3) (2020) 140-150 
kemampuan adaptasi dan kondisi lingkungan dari kedua jenis lichen, lichen Aspicilia calcarea ditemukan pada semua jenis pohon yang di amati sedangkan Verrucaria sp. hanya terdapat pada salah satu jenis pohon yaitu Soneratia alba dan juga pada salah satu jalur yaitu jalur I stasiun I tidak ditemukan sama sekali jenis lichen ini. Hal ini disebabkan karena kondisi lingkungan dan kemampuan adaptasi lichen yang tidak mampu hidup di lingkungan tesebut, dan juga mengapa tidak ditemukan sama sekali jenis lichen Verrucaria sp. pada jalur I stasiun I karena vegetasi pada jalur ini berhadapan langsung dengan lautan. Uap air laut akan menghambat petumbuhan lichen. Beberapa jenis lichen juga mengalami hal yang sama. Menurut Hadiyanti (2013: 12-17) bahwa kecepatan angin yang lebih tinggi, dapat menyebabkan penyerapan $\mathrm{SO}_{2}$ secara difusi oleh thallus lichen. Dalam hal ini sama kemampuan difusi $\mathrm{SO}_{2}$ sama dengan kemampuan difusi uap garam di pesisir pantai.

Aspicilia calcarea dan Aspicilia sp. dapat ditemukan pada semua jenis pohon yang diamati, hal ini dikarenakan tingkat toleransi terhadap kondisi lingkungan berbeda dengan tingkat toleransi jenis lichen yang lain. Menurut Panjaitan (2012: 19-21) bahwa perbedaan sensitifitas lichen tehadap polusi udara berkaitan erat dengan kemampuannya mengakumulasi polutan, begitu pula dengan kadar garam pada uap air laut, beberapa lichen memiliki sensitifitas yang rendah terhadap perubahan lingkungan.

Kedua jenis lichen di atas mewakili beberapa lichen yang masuk dalam kelompok lichen crustose. Banyak lichen crustose yang ditemukan, hal ini dapat kita simpulkan bahwa lichen crustose lebih mudah beradaptasi daripada lichen foliose. Menurut Hadiyanti (2013: 12-17) bahwa lichen dengan morfologi berbentuk crustose (berbentuk datar seperti kerak) memiliki perlekatan yang sangat kuat pada substratnya, sebaliknya foliose (thallus berbentuk seperti daun) memiliki perlekatan yang lemah pada substrat, sehingga mudah terlepas dari substratnya. Secara teoritis, cara hidup crustose yang menenggelamkan diri pada substrat, dapat terlindungi oleh tempat hidupnya. Dibandingkan dengan lichen foliose tubuhnya tidak terlindungi oleh inangnya. Fructose lebih sulit lagi untuk beradapatasi, karena tubuh lichen (thallus) bergantung bebas dan memanjang menjauhi inangnya. Dengan demikian tubuh lichen semakin rentan terhadap kerusakan akibat dari peubahan lingkungan.

Dibandingkan dengan penelitian sebelumnya yang dilakukan oleh Ruliansyah (2014: 54), penelitian ini bertujuan untuk mengetahui jenis-jenis lichen pada ekosistem mangrove di Desa Lebo. Hasil penelitian yang diperoleh pada penelitian ini ditemukan 7 jenis lichen yang terbagi atas dua kelompok yang berdasarkan tipe thallus yaitu 6 jenis lichen crustose dan 1 jenis lichen foliose. Hal ini serupa dengan hasil penelitian sebelumnya bahwa jenis lichen yang ditemukan umumnya didominasi oleh lichen crustose.

Keanekaragaman pada setiap jenis makhluk hidup sangat dipengaruhi oleh faktor fisik kimia lingkungan yang ada pada setiap komunitas seperti suhu, intensitas cahaya, pH tanah, uap air garam dan kelembaban. Faktor tersebut sangat mempengaruhi pertumbuhan dan perkembangan kehidupan jenis lichen. Berdasarkan penelitian yang telah dilakukan, menunjukkan nilai indeks keanekaragaman lichen yang didapatkan di hutan mangrove Desa Tomoli sebesar 2.225 yang menunjukkan bahwa keanekaragaman sedang yang terdapat pada kriteria $1 \leq \mathrm{H}^{\prime} \geq 3$. Bila dibandingkan dengan penelitian sebelumnya yang berada di pegunungan, hutan maupun perkebunan yang merupakan daerah yang lembab sangat beragam jenis yang ditemukan berbeda dengan penelitian kali ini yang berada di hutan mangrove lebih sedikit. Hal ini dikarenakan lokasi 
penelitian telah terpapar uap air garam sehingga hanya 10 jenis lichen yang mampu bertoleransi di lingkungan tersebut.

\section{KESIMPULAN DAN SARAN \\ Kesimpulan}

Berdasarkan penelitian yang telah dilakukan, keanekaragaman lichen yang didapatkan di Hutan Mangrove Desa Tomoli menunjukkan tingat keanekaragaman dalam kategori sedang $\left(\mathrm{H}^{\prime}=2.225\right)$.

\section{Saran}

Perlu dilakukan penelitian lebih lanjut di Hutan Mangrove Desa Tomoli mengenai jenis lichen apa yang paling toleransi terhadap uap air garam, agar dapat melengkapi informasi tentang karakteristik lichen di hutan mangrove tersebut.

\section{DAFTAR RUJUKAN}

Hadiyanti. (2013). Kandungan sulfur dan klorofil thallus lichen Parmelia sp dan Graphis sp pada pohon peneduh jalan di Kecamatan Pontianak Utara. Jurnal Protobiont, 2(1), 12-17.

Haeryn. (2012). Lichenes Lumut Kerak. Jakarta: PT. Rineka Cipta.

Ibansi. (2011). Keanekaragaman jenis lumut kerak (Lichen) di Kawasan Hutan Alami Dongi-dongi Taman Nasional Lore Lindu Kabupaten Sigi. [Skripsi]. Palu: Universitas Tadulako.

Istam, Y.C. (2007). Respon lumut kerak pada vegetasi pohon sebagai indikator pencemaran udara di Kebun Raya Bogor dan Hutan Kota Manggala Wana Bhakti. [Skripsi]. Bogor: Institut Pertanian Bogor.

Khaerulmaddy. (2010). Lumut Kerak (Lichen). Jakarta: PT. Rineka Cipta.

Mafaza, H., Murningsih, \& Jumari. (2019). Keanekaragaman jenis lichen di Kota Semarang. Life Science, 8(1), 10-16.

Magurran, A.E. (2004). Ecological diversity and its measurement. New Jersey: Princeton University Press.

Mahawati. (2011). Faktor-faktor resiko paparan Pb pada polusi lalu lintas di Semarang Barat. Jurnal Visikes, 10(2), 130-137.

Melanstica, E. (2016). Keanekaragaman jenis lichen pada ekosistem mangrove di Desa Kasimbar Utara Kecamatan Kasimbar Kabupaten Parigi Moutong untuk digunakan sebagai media pembelajaran. [Skripsi]. Palu: UNTAD.

Misra, A., \& Agrawal, R.P. (1978). Lichens (A Preliminary Text). New York: Oxford and IBH Publishing Co.

Murningsih, \& Mafaza, H. (2016). Jenis-jenis lichen di kampus UNDIP Semarang. Bioma, 18(1), 20-29.

Muzayyinah. (2005). Keanekaragaman Tumbuhan Tak Berpembuluh. Solo: Lembaga Pengembangan Pendidikan (LPP).

Panjaitan, D.M., Atria, M., \& Fitmawati. (2012). Keanekaragaman lichen sebagai bioindikator pencemaran udara di Kota Pekanbaru Provinsi Riau. [Skripsi]. Riau: Universitas Riau.

Ronoprawiro, S. (1989). Gulma Lumut dan Lumut Kerak Terhadap Pertumbuhan dan Hasil Teh (Camellia sinensis. L). Yogyakarta: Universitas Gajah Mada Press.

Roziaty, E. (2016). Morfologi, habitat dan bioindikator kualitas udara ambien akibat polusi kendaraan bermotor. Journal Program Studi Pendidikan Biologi FKIP Universitas Muhammadiyah Surakarta, 2(1), 54-66.

149 I Pratama \& Trianto /JBE 5 (3) (2020) 140-150 
Ruliansyah. (2014). Jenis-jenis lichen pada ekosistem mangrove di Desa Lebo Kecamatan Parigi Kabupaten Parigi Moutong dan implementasinya sebagai media pembelajaran biologi. [Skripsi]. Palu: UNTAD.

Savic, S. (1998). Epiphityc Lichens as Bioindicators of Air Pollution in the Area of Belgrade. Belgrade: Verlag Alexander Just.

Sudrajat, W. (2013). Keanekaragaman lichen corticolous pada tiga jalur di Kabupaten Kubu Raya. Jurnal Protobiont, 2(2), 75-79.

Sugiyono. (2010). Metode Penelitian Pendidikan Pendekatan Kuantitatif, Kualitatif, dan $R \& D$. Bandung: Alfabeta.

Suprianto, Trianto, M., Alam, N., \& Kirana, N.G.A.G.C. (2020). Karakter morfologi dan analisis daerah conserved gen elongation factor 1a (EF1a) pada Lepidotrigona terminata. Jurnal Metamorfosa, 7(2), 30-39.

Tarigan, S. (2008). Sebaran dan luas hutan mangrove di Wilayah Pesisir Teluk Pising Utara Pulau Kabaena Provinsi Sulawesi Tenggara. LIPI, 12(2), 108-112.

Tjitrosoepomo, G. (2009). Taksonomi Tumbuhan. Yogyakarta: Gadjah Mada University Press.

Trianto, M., \& Marisa, F. (2020). Diversity of bees and wasp (Hymenoptera) in cowpea (Vigna sinensis L.) in agricultural area at Martapura District, Banjar Regency, South Kalimantan. Journal of Science and Technology, 9(2), 29-33.

Trianto, M., \& Purwanto, H. (2020). Molecular phylogeny of stingless bees in the Special Region of Yogyakarta revealed using partial 16S rRNA mitochondrial gene. Buletin Peternakan, 44(4), 186-193.

Trianto, M., \& Purwanto, H. (2020). Morphological characteristics and morphometrics of Stingless Bees (Hymenoptera: Meliponini) in Yogyakarta, Indonesia. Biodiversitas, 21(6), 2619-2628.

Trianto, M., Kaini, Saliyem, Warsih, E., \& Winarsih. (2020). Keanekaragaman serangga polinator pada tanaman nanas (Ananas comosus (L.) Merr.) di Desa Bincau. Jurnal Penelitian Science dan Pendidikan, 9(2), 154-162.

Trianto, M., Marisa, F., \& Siswandari, N.P. (2020). Kelimpahan nisbi, frekuensi, dan dominansi jenis lalat di beberapa Pasar Tradisional di Kecamatan Martapura. Jurnal Metamorfosa, 7(2), 21-29.

Trianto, M., Marisa, F., \& Sukmawati. (2020). Keanekaragaman jenis rayap pada perkebunan kelapa sawit dan perkebunan karet di Kabupaten Banjar, Kalimantan Selatan. Jurnal Biologi Makassar, 5(2), 199-209.

Whitesel, T. (2006). Lichens: Two Lives in One. New York: Minnesota Conversation Young Naturalist.

Yurnaliza. (2002). Lichenes (karakteristik, klasifikasi, dan kegunaan). [Skripsi]. Sumatera Utara: Universitas Sumatera Utara. 